\title{
A Meta-Analysis of Field Bindweed Convolvulus arvensis Management in Annual and Perennial Systems
}

\section{Authors: Stacy Davis, Jane Mangold, Fabian Menalled, Noelle Orloff, Zach Miller, and Erik Lehnhoff}

This is a pre-copyedited, author-produced PDF of an article accepted for publication in Weed Science following peer review. The version of record, see full citation below, is available online at: https://dx.doi.org/10.1017/wsc.2018.25.

Davis, Stacy, Jane Mangold, Fabian Menalled, Noelle Orloff, Zach Miller, and Erik Lehnhoff. "A Meta-Analysis of Field Bindweed Convolvulus arvensis Management in Annual and Perennial Systems." Weed Science 66, no. 4 (July 2018): 540-547. DOI:10.1017/wsc.2018.25. 
Short title for running footer: Management of $C$. arvensis

\title{
A Meta-Analysis of Field Bindweed (Convolvulus arvensis) Management in Annual and Perennial Systems
}

\author{
Stacy Davis ${ }^{1 *}$, Jane Mangold $^{2}$, Fabian Menalled $^{3}$, Noelle Orloff $^{4}$, Zach Miller $^{5}$, and Erik \\ Lehnhoff ${ }^{6}$
}

Field bindweed (Convolvulus arvensis L.) is a persistent, perennial weed species that infests a variety of temperate habitats around the globe. To evaluate the efficacy of general management

\footnotetext{
${ }^{1}$ Research Associate (0000-0002-0287-3871), Montana State University, Department of Land Resources and Environmental Sciences, Bozeman, MT, 59717;

${ }^{2}$ Associate Professor, Montana State University, Department of Land Resources and Environmental Sciences, Bozeman, MT, 59717;

${ }^{3}$ Professor, Montana State University, Department of Land Resources and Environmental Sciences, Bozeman, MT, 59717;

${ }^{4}$ Associate Extension Specialist, Schutter Diagnostic Lab, Montana State University, Bozeman, MT 59717;

${ }^{5}$ Assistant Professor and Superintendent, Western Agricultural Research Center, Montana State University, Corvallis, MT 59828;

${ }^{6}$ Assistant Professor, Department of Entomology, Plant Pathology, and Weed Science, New Mexico State University, Las Cruces, NM 88003
}

Author for correspondence: Stacy Davis, Research Associate, Montana State University, PO Box 173120, Bozeman, MT 59717. (E-mail: stacy.davis1@montana.edu) 
approaches and impacts on crop yield, as well as identify research gaps, we conducted a series of meta-analyses using published studies focusing on C. arvensis management in annual cropping and perennial systems. Our analysis of 48 articles (560 data points) conducted in annual systems indicated that $95 \%$ of data points measured efficacy over short time frames (within two years of treatment). Furthermore, only $27 \%$ of data points reported impacts of $C$. arvensis management on crop yield. In annual systems, herbicide control dominated the literature ( $~ 80 \%$ of data points) and was an effective management technique up to two years post-treatment. Integrated management, with or without herbicides, and three non-chemical techniques were similarly effective as herbicide at reducing $C$. arvensis up to two years post-treatment. In addition, integrated approaches, with or without herbicides, and two non-chemical techniques had positive effects on crop yield. There were few differences among herbicide mechanism of action groups on $C$. arvensis abundance in annual systems. There were only 9 articles (28 data points) concerning C. arvensis management in perennial systems (e.g., pasture, rangeland, lawn), indicating more research effort has been placed in annual systems. In perennial systems, biocontrol, herbicide, and non-herbicide integrated management techniques were equally effective at reducing $C$. arvensis, while competition and grazing were not effective. Overall, our results demonstrate that while chemical control of $C$. arvensis is generally effective and wellstudied, integrated and non-chemical control practices can perform equally well. We also documented the need for improved monitoring of the efficacy of management practices over longer time frames and including effects on desired vegetation to develop sustainable weed management programs.

Key words: integrated management, invasive plants, literature review, noxious weeds, perennial weeds. 
Field bindweed (Convolvulus arvensis L.) is a persistent, perennial species that was first introduced to North America from Eurasia in the 1700s (Weaver and Riley 1982). While the exact vector by which this species was introduced to North America is unknown, it is possible that it was through a contaminant of crop seeds (Anderson 1999). Convolvulus arvensis is among the top ten most frequently listed noxious weeds in the United States and Canada (Skinner et al. 2000) and is on 22 state noxious weed lists (USDA 2018). It can be found in a variety of climates, ranging from temperate to Mediterranean, and across most parts of the United States, Canada, and in parts of Africa, South America, Southeast Asia, Australia, and the Pacific Islands (Weaver and Riley 1982). Convolvulus arvensis grows on a variety of soils and occurs across a wide range of settings such as agricultural fields, pastures, lawns, roadsides, and other disturbed areas, making this plant a widespread weed (Weaver and Riley 1982).

The ability of $C$. arvensis to invade and persist in a variety of habitats can be explained by its specific traits. Convolvulus arvensis is capable of vegetative reproduction through adventitious buds on its extensive root system, and its long-lived seeds (e.g., 20 or more years) further complicate management (Timmons 1949; Weaver and Riley 1982). Convolvulus arvensis can store carbohydrate reserves in its roots, enhancing survival and making management more challenging (Wiese and Rea 1962). Additionally, certain management techniques such as mechanical disturbance can exacerbate the problem by spreading vegetative propagules (Hakansson 2003).

Convolvulus arvensis has direct and indirect economic impacts across agricultural systems. Convolvulus arvensis has a twining growth habit, forming dense tangled mats that can interfere with harvest procedures in annual cropping systems (Weaver and Riley 1982). It competes for soil moisture and nutrients, resulting in reduced crop yield (Weaver and Riley 
1982). Boldt et al. (1998) estimated that C. arvensis infestations resulted in crop losses of over $\$ 377$ million per year in 10 selected states in the United States. Impacts of $C$. arvensis in rangelands and perennial forage systems are not as well documented, but perennial weeds such as $C$. arvensis can have effects on perennial systems including decreased forage production and native plant diversity, toxicity to livestock, and changes to ecological function (DiTomaso 2000). Convolvulus arvensis has been noted as a problematic weed in turfgrass (Guntli et al. 1998; Timmons 1950) and is a concern in perennial pastures as it contains alkaloids that are toxic in high doses and can cause digestive disturbances to pigs and horses (Burrows and Tyrl 2013; Todd et al. 1995). While $C$. arvensis is not as competitive in perennial pastures and forages compared to annual cropping systems, controlling this species is particularly critical if perennial systems are going to be rotated into annual crop production where $C$. arvensis can result in significant yield and economic losses (Boldt et al. 1998).

Although stand-alone tactics, such as repeated use of cultivation (Bell 1990) and herbicides (Westra et al. 1992; Wiese and Rea 1959), along with integrated management techniques (Wiese and Rea 1959) have been suggested as viable approaches to managing $C$. arvensis, it continues to invade and persist in temperate regions of the world. Reviewing previous literature and systematically summarizing results from past studies may improve management strategies for $C$. arvensis, and meta-analysis is a useful statistical tool to achieve this goal (Koricheva and Gurevitch 2014). Meta-analyses are frequently used in agronomy to identify promising management practices for maximizing crop production or quality, or for reducing pest pressure (Philibert et al. 2012). For example, through a meta-analysis of 100 articles, Davis et al. (2018) found that while herbicides may control the problematic weed Canada thistle [Cirsium arvense (L.) Scop.], integrated multi-tactic techniques were more 
effective than herbicides alone for long-term control in both annual cropping systems and perennial systems.

We conducted a series of meta-analyses to systematically review and summarize results from previously published studies involving $C$. arvensis management in annual cropping (row crop and fallow fields) and perennial (pasture, rangeland, and natural areas) systems. We analyzed annual cropping system studies separately from perennial systems, but due to the limited number of studies in perennial systems, some objectives could only be assessed in annual systems. Our objectives were to 1) assess the effectiveness of weed management techniques for controlling C. arvensis, 2) compare short- and long-term efficacy of different herbicide mechanism of action (MOA) groups for controlling C. arvensis in annual cropping systems, 3) compare effects of management techniques for C. arvensis on crop yield, and 4) identify research gaps in the management of $C$. arvensis.

\section{Materials and Methods}

We performed the literature search and series of meta-analyses on C. arvensis management following procedures described in Davis et al. (2018). Briefly, we first conducted a literature search in September 2015 using the Web of Science® (1864-2015) and Agricola® (1927-2015) databases using the keywords "Convolvulus arvensis," "field bindweed," "creeping jenny," and "perennial morning glory." This resulted in 1,290 records after duplicates from the two databases were removed (Figure 1). Following guidelines by Koricheva et al. (2013), all references underwent a filtering and inclusion process identical to Davis et al. (2018) in which 1,290 abstracts and titles were screened for relevancy, and the subsequent 482 full texts were examined to see if studies met our pre-established inclusion criteria (Figure 1). We included field 
studies that were replicated and examined the relative efficacy of stand-alone or integrated weed management techniques taking place in annual cropping or perennial systems. We recorded means, measures of variation, and sample sizes for both control and treatment plots from text, tables, or figures of the selected literature following Gurevitch and Hedges (2001). Means were quantitative response measurements for aboveground density, cover, biomass, frequency, survival, or percent control of C. arvensis. We extracted additional information on type of system (annual versus perennial), study duration, and details of the treatment applied (e.g., herbicide type and rate, herbicide MOA group). Data points using herbicides were included only if the applied herbicide was approved for use in the United States and if it was applied within label recommended rates (Greenbook 2017; Shaner 2014). Herbicide MOA groups were as follows: 2 [acetolactate synthase (ALS) or acetohydroxy acid synthase (AHAS) inhibitors], 3 [inhibitors of microtubule assembly], 4 (synthetic auxins), $5+6+7$ (inhibitors of photosynthesis at photosystem II site A or B), 9 [inhibitor of 5-enolypyruvyl-shikimate-3-phosphate synthase (EPSPS)], 14 [inhibitors of protoporphyrinogen oxidase], 15 [inhibitors of synthesis of very long-chain fatty acids (VLCFA)], and 27 [inhibitors of 4-hydroxyhenyl-pyruvatedioxygenase (4HPPD)] (Shaner 2014). We included a "mix" herbicide MOA group, which we defined as an herbicide application including two or more herbicides from different MOA groups. We also extracted data, when available, on crop yield to examine how $C$. arvensis management techniques impacted annual crop yields.

Following Davis et al. (2018), we used the log response ratio (lnR) as our effect size measurement, where

$$
\ln \mathrm{R}=\ln \left(\mathrm{X}^{\mathrm{E}} / \mathrm{X}^{\mathrm{C}}\right)
$$


and $\mathrm{X}^{\mathrm{E}}$ and $\mathrm{X}^{\mathrm{C}}$ are means of experimental (treated) and control (non-treated) groups, respectively (Hedges et al. 1999). For example, a 50\% reduction in C. arvensis relative to a control group is equivalent to an effect size of -0.7 . We selected the response ratio for our analyses because it can be estimated without knowledge of sample sizes or variances (Adams et al. 1997), as only $6 \%$ of data points from annual cropping systems and $4 \%$ of data points from perennial systems reported measures of variation. The response ratio cannot be calculated when data points have response measurements equal to zero because one cannot take a logarithm of a zero value (Koricheva et al. 2013). Furthermore, transformation of data points by adding a small number to the numerator and denominator of the ratio usually results in abnormally large effect size estimates and is not recommended (Koricheva et al. 2013). Therefore, 30 data points from annual cropping systems ( $5 \%$ of data) and 7 data points from perennial systems (20\% of data) were excluded from the analyses.

We used a nonparametric bootstrapping approach similar to Adams et al. (1997), weighting each response ratio using sample sizes with the function $\mathrm{F}_{\mathrm{N}}$, where

$$
\mathrm{F}_{\mathrm{N}}=\left(\mathrm{n}_{\mathrm{E}} \times \mathrm{n}_{\mathrm{C}}\right) /\left(\mathrm{n}_{\mathrm{E}}+\mathrm{n}_{\mathrm{C}}\right)
$$

and $\mathrm{n}_{\mathrm{E}}$ and $\mathrm{n}_{\mathrm{C}}$ represent the number of replicates for the experimental (treated) and control (nontreated) groups, respectively. We used bootstrapping methods to calculate $95 \%$ confidence intervals around the pooled effect size mean with 1,000 iterations for each management technique or herbicide MOA group (Adams et al. 1997). Individual management techniques or herbicide MOA groups were considered effective at reducing $C$. arvensis if the mean response ratio was negative and the $95 \%$ confidence interval did not overlap zero (Adams et al. 1997; Gurevitch et al. 1992). Mean response ratios from different management techniques or herbicide MOA groups were considered different from one another if their $95 \%$ confidence intervals did 
not overlap (de Graaff et al. 2006; Ferreira et al. 2015). Management techniques or herbicide MOA groups that only had one data point were included in figures to note knowledge gaps and were not compared statistically to other management techniques or herbicide MOA groups because confidence intervals could not be calculated. All summaries and analyses were conducted in R statistical software (version 3.3.2), including the “plyr”, "ggplot2”, and “cowplot” packages (R Core Team 2016).

We conducted separate meta-analyses corresponding to each objective. First, we evaluated efficacy of management techniques for C. arvensis control separately for annual cropping and perennial systems (Table 1). In addition to stand-alone practices, we included the categories of herbicide integrated (i.e., any combination of two or more management techniques with at least one method using herbicides) and non-herbicide integrated (i.e., combination of two or more management techniques, none including herbicides). In annual cropping systems, we only used response measurements that considered a single year of treatment to accurately compare short- and long-term effectiveness of $C$. arvensis management. While land managers may conduct management strategies every year for multiple years in a row, we wanted to make valid comparisons between management techniques in different time periods as is commonly evaluated in the literature. If responses to a single year of treatment were measured over multiple dates, we extracted data from three defined time periods ( $<1$ year, 1-2 years, and $>2$ years after treatment) when possible and conducted separate analyses to compare management across different study durations. Next, we examined efficacy of different herbicide MOA groups in annual cropping systems using the same time periods as with our general management techniques. Finally, for annual cropping systems we compared the effect of management techniques on crop yield. For this analysis, a positive response ratio indicated an increase in 
yield, while $95 \%$ confidence intervals overlapping zero indicated we could not detect an effect of the management technique on yield (Gurevitch et al. 1992).

In perennial systems, we conducted one meta-analysis examining general management techniques because there were insufficient data (28 data points total) to split the analysis into time periods or herbicide MOA groups, or to examine how management impacted desired plant communities. We did not compare additional specifics of individual management techniques (e.g., timing, types of biocontrol agents, herbicide rates) because this level of detail was outside the scope of our questions of interest, and there was insufficient replication of specific practices within management techniques to adequately compare them.

\section{Results and Discussion}

Convolvulus arvensis Management in Annual Cropping Systems. From a total of 1,290 records, we extracted data from 48 articles published between 1947 and 2015 (Supplementary Appendix S1), resulting in 560 total data points (Figure 1). The majority of these studies were conducted in North America (28 articles), while the remaining took place in South Asia (12 articles), Europe ( 7 articles), and Australia (1 article). Studies took place across a variety of cropping systems (e.g., wheat (Triticum aestivum L.), corn (Zea mays L.), bean (Phaseolus vulgaris L.)) as well as fallow fields (Supplementary Table S1).

Six management techniques were effective at reducing $C$. arvensis $<1$ year posttreatment: competition, herbicide, herbicide integrated, mulch, non-herbicide integrated, and soil disturbance (Figure 2a). Bioherbicide, fertilizer, and grazing had no effect on C. arvensis $<1$ year post-treatment (Figure 2a). Only two management techniques were examined 1-2 years posttreatment: herbicide and herbicide integrated, and both were equally effective (Figure 2b). 
Herbicide was the only management technique investigated $>2$ years post-treatment $(n=26)$, and a single application was not effective at reducing $C$. arvensis, suggesting the re-application of herbicides is necessary for effective long-term management (Figure 2c).

Herbicide, which was the most frequently evaluated management technique (included in almost $80 \%$ of annual cropping system data points), performed similarly to other effective management practices. Five non-chemical and integrated management techniques were as effective as herbicide within the first year of treatment (Figure 2a) and herbicide integrated was as effective as herbicide 1-2 years post-treatment (Figure 2b). Our results are similar to a metaanalysis on Cirsium arvense management in which herbicide was the most studied management technique, yet integrated management, with or without herbicides, was as effective as or more effective than sole use of herbicides (Davis et al. 2018). The economics associated with different management strategies may influence which strategy is the best choice for managers, especially if two appear to be equally effective. An evaluation of the best set of management practices to control $C$. arvensis should include not only the potential economic advantages of herbicides but also the environmental, social, and biological consequences (e.g., herbicide resistance and nontarget effects) of such decisions (Liebman et al. 2001). Although conventional agriculture relies heavily on synthetic herbicides to manage weeds, this can potentially lead to overuse and the selection of herbicide resistant biotypes (McErlich and Boydston 2014; Menalled et al. 2016). While the occurrence of herbicide resistance across $C$. arvensis populations is relatively rare, one case of resistance to paraquat has been reported (Ghosheh and Hurle 2011). In addition, DeGennaro and Weller (1984) reported differential sensitivity of $C$. arvensis wild biotypes to glyphosate, suggesting that the selection of resistant biotypes could occur. 
Overall, there were few differences among herbicide MOA groups in terms of efficacy on C. arvensis in annual systems. Nine of the twelve herbicide MOA groups examined within one year post-application reduced $C$. arvensis and most were similarly effective (Figure 3a). Herbicide MOA Group 7 was the only ineffective herbicide MOA group, but data were limited for this group $(\mathrm{n}=2)$. While herbicide MOA Groups 8 and 27 had negative effect sizes, they only had one data point each so comparisons to other herbicide MOA groups cannot be made. Six herbicide MOA groups were examined 1-2 years post-application and half were effective at reducing $C$. arvensis (herbicide MOA Groups 4, 9, and a mix of groups; Figure 3b). Herbicide MOA Group 2 had no effect on $C$. arvensis abundance, and herbicide MOA Groups 14 and 27 had one data point each so comparisons to other herbicide MOA groups were not made. Only herbicide MOA Groups 4 and 9 were examined for efficacy $>2$ years post-application, and neither were effective for this time period (Figure 3c).

Our results showed that some herbicide MOA groups have been studied more than others for $C$. arvensis management. Herbicide MOA Groups 4 and 9 were the most studied groups across all time periods (61\% and $12 \%$, respectively) and were the only groups assessed for longterm efficacy (Figure 3a, b, and c). These two groups include systemic herbicides which translocate to the root system, potentially providing long-term control for weeds that can resprout from underground structures (Lindenmayer et al. 2013). Common MOA Group 4 herbicides used in studies included 2,4-D (24\%), dicamba (13\%), and a mix of two or more Group 4 herbicides (44\%). Other MOA Group 4 herbicides making up 19\% of data points included dichlorprop, fluroxypyr, MCPA, MCPB, mecoprop, picloram, quinclorac, and triclopyr. MOA Group 9 herbicides (glyphosate) were used in $12 \%$ of data points across all time periods. 
In our selected literature, $27 \%$ of data points reported on how various management techniques for C. arvensis impacted crop yield, specifically corn, flax (Linum usitatissimum L.), lentils (Lens culinaris Medik.), mustard (Brassica cretica L.), potatoes (Solanum tuberosum L.), sorghum [Sorghum bicolor (L.) Moench], and wheat (Figure 4). Convolvulus arvensis management via herbicide $(n=119)$ or soil disturbance $(n=5)$ did not have a positive effect on crop yield relative to untreated controls, suggesting that competition with $C$. arvensis was not limiting crop production. Other environmental or biological variables (e.g., soil nutrient and moisture status, crop injury, pathogen or pest pressure, etc.) may have been more limiting in the studied conditions. All other management techniques (i.e., competition, fertilizer, and integrated management with or without herbicides) improved crop yield. While fertilizer increased crop yield, it was not an effective technique for $C$. arvensis management (Figure 2a). Integrated multitactic techniques, with or without herbicide use, resulted in improved crop yield but were studied less frequently ( $\mathrm{n}=2$ and 8 , respectively) than herbicide alone ( $\mathrm{n}=119)$.

Convolvulus arvensis Management in Perennial Systems. There were relatively few studies on managing $C$. arvensis in perennial systems compared to annual cropping systems. We extracted data from nine articles published between 1947 and 2010 (Supplementary Appendix S2), resulting in 28 total data points (Figure 1). The majority of these studies took place in North America (6 articles), and the remaining took place in Europe. Studies were conducted in forage fields, pastures, and lawn/turf (Supplementary Table S2).

Six different management techniques were studied in perennial systems: biocontrol, competition, grazing, herbicide, non-herbicide integrated, and solarization. Half of these techniques (biocontrol, herbicide, and non-herbicide integrated management) were equally effective at reducing C. arvensis (Figure 5). Non-herbicide integrated management strategies 
used in perennial systems included combining competition (i.e., grass seeding) and water manipulation (Timmons 1950), as well as competition (i.e., grass seeding) and biocontrol (i.e., the fungus Sclerotinia minor) (Abu-Dieyeh and Watson 2007). Competition and grazing had no effect on $C$. arvensis in perennial systems (Figure 5). Only one data point existed for the impact of solarization on $C$. arvensis so comparisons with other management techniques could not be made.

Overall, low sample sizes among individual management techniques $(n<10)$ limited our inference within perennial systems and did not allow us to examine management techniques' effectiveness in different time periods or across herbicide MOA groups. Also, due to the lack of reported studies, we were unable to analyze how $C$. arvensis management techniques impacted abundance of desired plants or any other ecosystem service provided by perennial systems. Research Gaps. Despite the importance of long-term control and impacts to crop yield in the management of $C$. arvensis, we found relatively few studies that investigated these factors. Our meta-analyses in annual cropping systems showed that most management techniques were examined $<1$ year after treatment, highlighting the importance of following studies beyond a growing season to develop sustainable weed management programs. Similarly, in a review of invasive plant control research papers, Kettenring and Adams (2011) found that the time frames of most studies were short; $51 \%$ evaluated control after one growing season or less. Furthermore, our results showed that certain management techniques that are effective within a year of applying may not be effective after two years. We also found that almost $75 \%$ of data points from our analysis did not describe how a particular management practice impacted crop yield, emphasizing the need for holistic studies that measure the effects of weed management on desired species. 
Our results showed that herbicide was the most frequently studied management technique in both annual cropping and perennial systems, but there were other less-studied management techniques that were equally effective as herbicides (i.e., integrated practices and certain nonchemical practices). In addition to being understudied, we found that many management techniques included in our meta-analyses only took place in one country (e.g., bioherbicide [United States], fertilizer [India], grazing [United States], mulch [Greece]), suggesting the need to evaluate techniques in a broader diversity of environments. When combining weed management practices, techniques may interact to alter the effects on efficacy, crop performance, or environmental services in either positive or negative ways, and these interactions may be contingent on the environment and cropping system. Researching non-chemical management practices will provide land managers with broader options for long-term management of $C$. arvensis. However, switching to more non-chemical management practices will require a major shift in research priorities across public and private sectors (Young et al. 2017). For example, $\$ 2.52$ billion was spent in 2014 by leading crop protection companies to conduct research and development on chemical control, but less than ten percent of that amount ( $\$ 180$ million) was spent to assess the potential efficacy of biological control products (McDougall 2016). The shift to more non-chemical management practices also suggests the need for an interdisciplinary approach to address economic, ecological, and crop yield considerations of different management options compared to traditional weed management approaches (Ward et al. 2014).

We found that some herbicide MOA groups have been widely studied for C. arvensis management in annual cropping systems (e.g., MOA Groups 4, 9, 14, mixes), but there are other herbicide MOA groups that show promise yet have been researched less frequently. For example, investigating the potential of herbicide MOA Groups 14 and 27 may be beneficial to 
weed management as these groups had negative effect sizes 1-2 years post-application but only

had a sample size of one data point. Herbicide labels within these MOA groups claim to provide some control of perennial weed species similar to $C$. arvensis.

Given that $C$. arvensis is on many states' noxious weed lists, we were surprised by the paucity of studies that tested management techniques in perennial systems. We recommend careful examination of the impacts of $C$. arvensis in such systems, and if significant, further research in this area. Additionally, few studies ( $<10 \%$ of data points) in our meta-analyses included estimates of variability; reporting such measures of variation can expand upon possible meta-analytical approaches used in the future.

\section{Acknowledgements}

The authors would like to thank the Montana Noxious Weed Trust Fund and the Montana Wheat and Barley Committee for funding this research. We appreciate Sean McKenzie for assistance with statistical analysis. No conflicts of interest have been declared. 


\section{References}

Abu-Dieyeh MH, Watson AK (2007) Grass overseeding and a fungus combine to control Taraxacum officinale. J Appl Ecol 44:115-124

Adams DC, Gurevitch J, Rosenberg MS (1997) Resampling tests for meta-analysis of ecological data. Ecology 78:1277-1283

Anderson WP (1999) Field bindweed (Convolvulus arvensis). Pages 123-135 in Anderson WP, ed. Perennial Weeds: Characterestics and Identification of Selected Herbaceous Species. Iowa, United States: Iowa State University Press

Bell CE (1990) Non chemical control of field bindweed. Pages 74-77 in Proceedings of the California Weed Conference. San Jose, CA

Boldt PE, Rosenthal SS, Srinivasan R (1998) Distribution of field bindweed and hedge bindweed in the USA. J Prod Agric 11:291-381

Burrows G, Tyrl R (2013) Convolvulaceae Juss. Pages 365-375 in Burrows G, Tyrl R, eds. Toxic Plants of North America. Iowa: John Wiley \& Sons, Inc.

Davis S, Mangold J, Menalled F, Orloff N, Miller Z, Lehnhoff E (2018) A meta-analysis of Canada thistle (Cirsium arvense) management. Weed Sci: 1-10, 10.1017/wsc.2018.6

DeGennaro FP, Weller SC (1984) Differential sensitivity of field bindweed (Convolvulus arvensis) biotypes to glyphosate. Weed Sci 32:472-476

de Graaff M-A, van Groenigen K-J, Six J, Hungate B, van Kessel C (2006) Interactions between plant growth and soil nutrient cycling under elevated $\mathrm{CO}_{2}$ : a meta-analysis. Glob Change Biol 12:2077-2091 
DiTomaso JM (2000) Invasive weeds in rangelands: Species, impacts, and management. Weed Sci 48:255-265

Ferreira V, Castagneyrol B, Koricheva J, Gulis V, Chauvet E, Graca MA (2015) A meta-analysis of the effects of nutrient enrichment on litter decomposition in streams. Biol Rev Camb Philos Soc 90:669-688

Ghosheh HZ, Hurle K (2011) Variations in morphology, phenology, and herbicide sensitivity of field bindweed (Convolvulus arvensis) populations from Jordan. Jordan J Agr Sci 7:634643

Greenbook (2017) Plant Protection Label Data. https://www.greenbook.net. Accessed: December 6,2016

Guntli D, Pfirter HA, Moenne-Loccoz Y, Defago G (1998) Stagonospora convolvuli LA39 for biocontrol of field bindweed infesting cotoneaster in a cemetery. HortScience 33:860-861

Gurevitch J, Hedges LV (2001) Meta-analysis. Pages 347-369 in Scheiner SM, Gurevitch J, eds. Design and Analysis of Ecological Experiments. New York: Oxford University Press, Inc.

Gurevitch J, Morrow LL, Wallace A, Walsh JS (1992) A meta-analysis of competition in field experiments. Am Nat 140:539-572

Hakansson S (2003) Weeds with diverse life forms in various types of crops. Pages 16-55 in Hakansson S, ed. Weeds and Weed Management on Arable Land: An Ecological Approach. UK: CABI Publishing

Hedges LV, Gurevitch J, Curtis PS (1999) The meta-analysis of response ratios in experimental ecology. Ecology 80:1150-1156 
Kettenring KM, Adams CR (2011) Lessons learned from invasive plant control experiments: a systematic review and meta-analysis. J Appl Ecol 48:970-979

Koricheva J, Gurevitch J (2014) Uses and misuses of meta-analysis in plant ecology. J Ecol $102: 828-844$

Koricheva J, Gurevitch J, Mengersen K (2013) Handbook of Meta-analysis in Ecology and Evolution. Princeton, New Jersey: Princeton University Press. 498 p

Liebman M, Mohler CL, Staver CP (2001) Ecological management of agricultural weeds. Cambridge University Press. 546 p

Lindenmayer RB, Nissen S, Westra P, Shaner DL, Brunk G (2013) Aminocyclopyrachlor absorption, translocation and metabolism in field bindweed (Convolvulus arvensis). Weed Sci 61:63-67

McDougall P (2016) The Cost of New Agrochemical Product Discovery, Development and Registration in 1995, 2000, 2005-8 and 2010 to 2014. United Kingdom. 41 p

McErlich AF, Boydston RA (2014) Current state of weed management in organic and conventional cropping systems. Pages 11-32 in Young SL, Pierce FJ, eds. Automation: The Future of Weed Control in Cropping Systems. New York London: Springer

Menalled F, Peterson R, Smith R, Curran W, Páez D, Maxwell B (2016) The eco-evolutionary imperative: Revisiting weed management in the midst of an herbicide resistance crisis. Sustainability-Basel 8:1297, 10.3390/su8121297

Philibert A, Loyce C, Makowski D (2012) Assessment of the quality of meta-analysis in agronomy. Agr Ecosyst Environ 148:72-82

R Core Team (2016) R: A language and environment for statistical computing. Vienna, Austria: R Foundation for Statistical Computing 
Shaner DL, ed. (2014) Herbicide Handbook. 10th ed. Champaign, IL: Weed Science Society of America.

Skinner K, Smith L, Rice P (2000) Using noxious weed lists to prioritize targets for developing weed management strategies. Weed Sci 48:640-644

Timmons FL (1949) Duration of viability of bindweed seed under field conditions and experimental results in the control of bindweed seedlings. Agron J 41:130-133

Timmons FL (1950) Competitive relationships of four different lawn grasses with field bindweed and dandelion under frequent close clipping. Ecology 31:1-5

Todd FG, Stermitz FR, Schultheiss PC, Knight AP, Traubdargatz JL (1995) Tropane alkaloids and toxicity of Convolvulus arvensis. Phytochemistry 39:301-303

USDA (2018) The PLANTS Database https://plants.usda.gov/core/profile?symbol=COAR4. Accessed: April 5, 2018

Ward SM, Cousens RD, Bagavathiannan MV, Barney JN, Beckie HJ, Busi R, Davis AS, Dukes JS, Forcella F, Freckleton RP, Gallandt ER, Hall LM, Jasieniuk M, Lawton-Rauh A, Lehnhoff EA, Liebman M, Maxwell BD, Mesgaran MB, Murray JV, Neve P, Nuñez MA, Pauchard A, Queenborough SA, Webber BL (2014) Agricultural weed research: A critique and two proposals. Weed Sci 62:672-678

Weaver SE, Riley WR (1982) The biology of Canadian weeds. 53. Convolvulus arvensis L. Can J Plant Sci 62:461-472

Westra P, Chapman P, Stahlman PW, Miller SD, Fay PK (1992) Field bindweed (Convolvulus arvensis) control with various herbicide combinations. Weed Technol 6:949-955

Wiese AF, Rea HE (1959) Bindweed (Convolvulus arvensis L.) control and seedling emergence as affected by tillage, 2,4-D, and competitive crops. Agron J 51:672-675 
Wiese AF, Rea HE (1962) Factors affecting the toxicity of phenoxy herbicides to field bindweed. Weeds-U 10:58-61

Young SL, Pitla SK, Van Evert FK, Schueller JK, Pierce FJ (2017) Moving integrated weed management from low level to a truly integrated and highly specific weed management system using advanced technologies. Weed Res 57:1-5 


\section{Tables}

Table 1. Descriptions of Convolvulus arvensis management techniques used in articles included in meta-analyses. The number of data points associated with each type of system is indicated.

\begin{tabular}{|c|c|c|c|}
\hline Management technique & Description & Annual cropping & Perennial \\
\hline Biocontrol & $\begin{array}{l}\text { Biological control using insects or } \\
\text { pathogens }\end{array}$ & 0 & 8 \\
\hline Bioherbicide & Plant extract used as herbicide & 4 & 0 \\
\hline Competition & $\begin{array}{l}\text { Any method attempting to increase } \\
\text { competitive ability including } \\
\text { manipulating row spacing or } \\
\text { revegetation }\end{array}$ & 9 & 4 \\
\hline Fertilizer & $\begin{array}{l}\text { Soil amendments including fertilizer } \\
\text { or manure }\end{array}$ & 8 & 0 \\
\hline Grazing & $\begin{array}{l}\text { Using animals to graze target } \\
\text { species }\end{array}$ & 2 & 2 \\
\hline Herbicide & Applying herbicides & 445 & 9 \\
\hline Herbicide integrated & $\begin{array}{l}\text { Any combination of two or more } \\
\text { management techniques with at least } \\
\text { one method using herbicides }\end{array}$ & 66 & 0 \\
\hline Mulch & $\begin{array}{l}\text { Use of either plastic or organic } \\
\text { mulches }\end{array}$ & 3 & 0 \\
\hline
\end{tabular}


Non-herbicide

integrated

Soil disturbance

Solarization
Combination of two or more

management techniques, none

including herbicides

Mechanical control methods

including tillage, cultivation, hoeing,

or harrowing

Heating the soil by using dark or

translucent plastics
11

4

12

0

0

1 


\section{Figures}

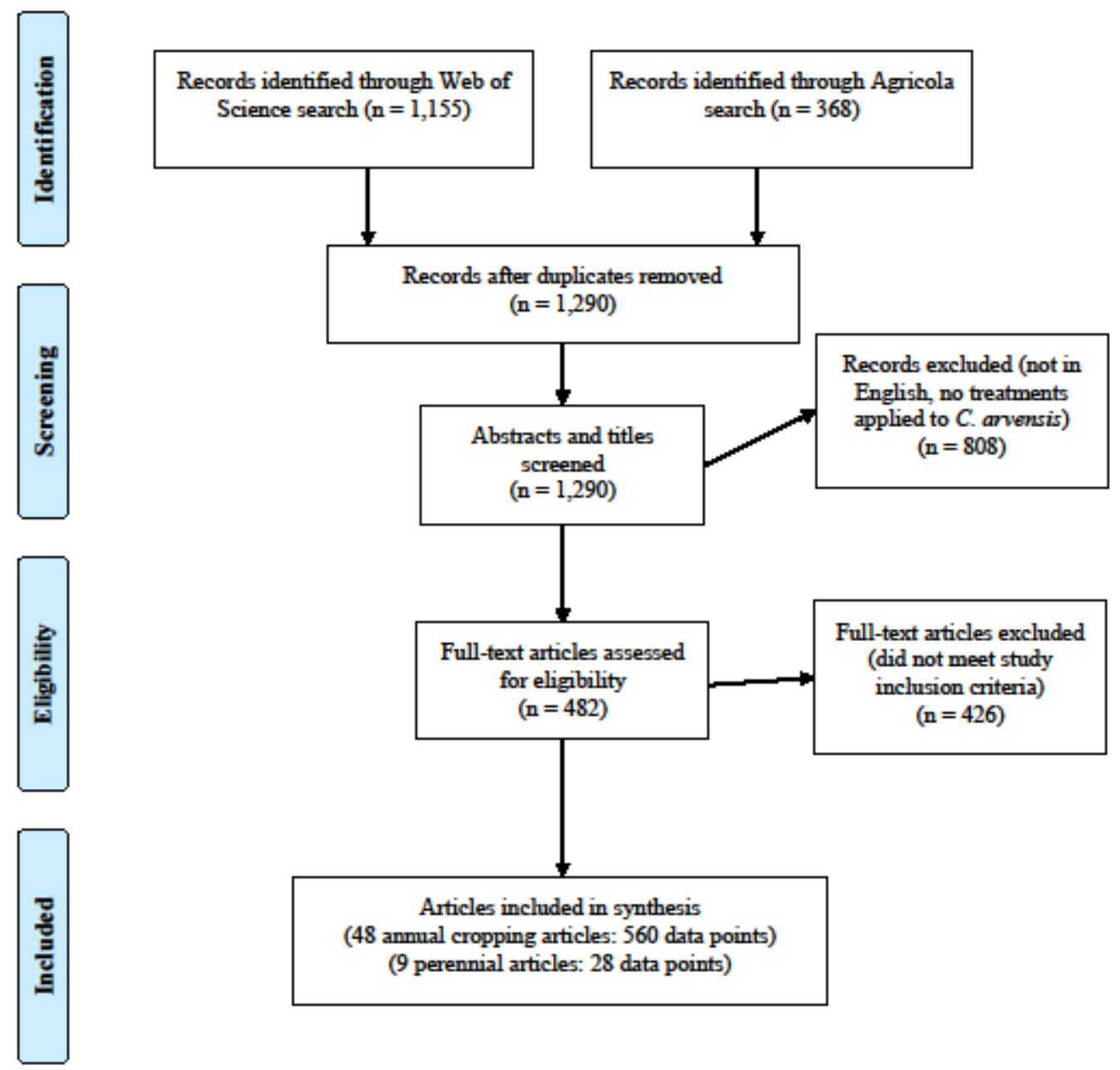

Figure 1. Flow diagram depicting criteria applied during literature screening portion of the metaanalysis of Convolvulus arvensis management. In each box, " $n$ " is the number of articles described in that step. 

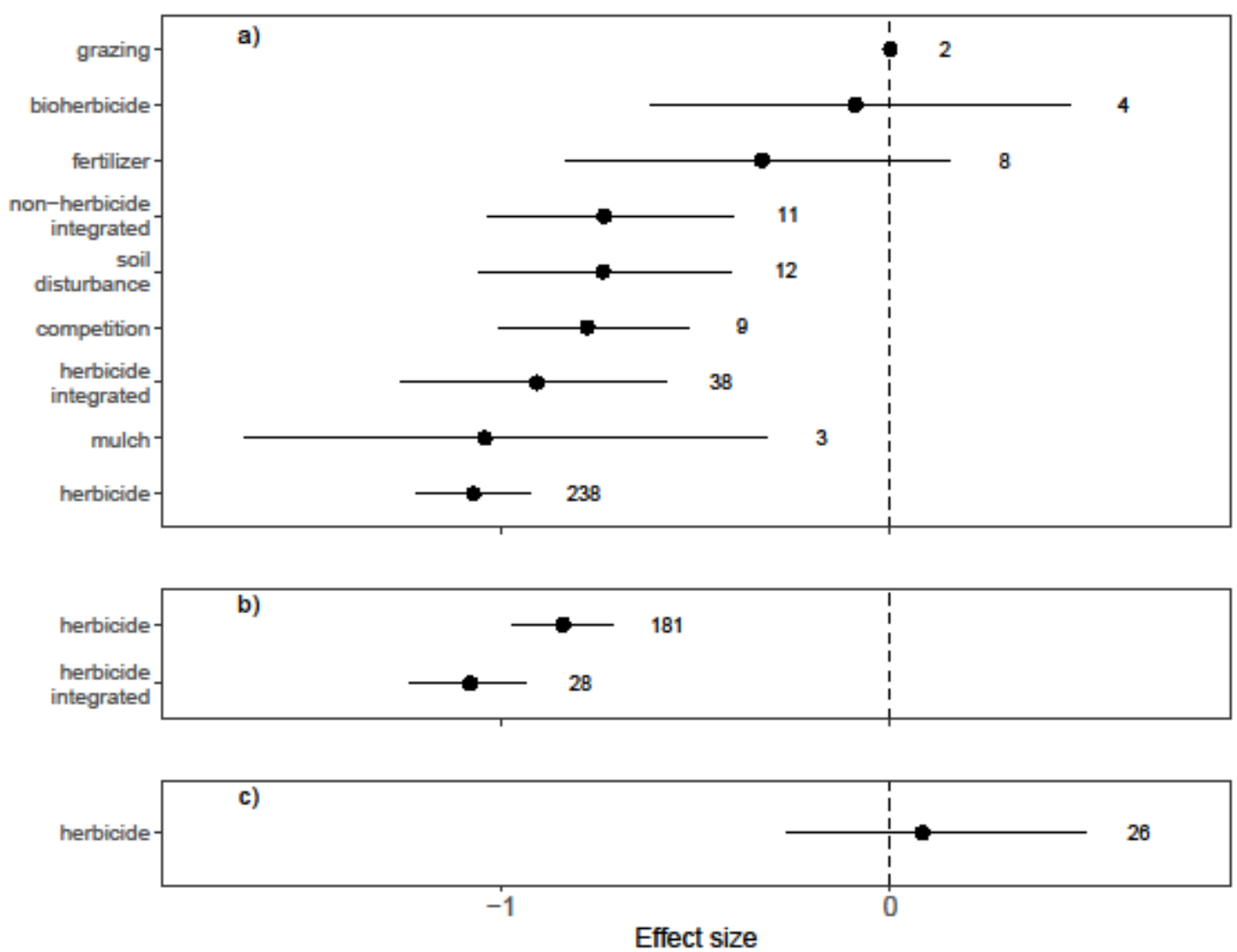

Figure 2. Mean effect size $(\operatorname{lnR})$ and $95 \%$ confidence intervals for Convolvulus arvensis abundance measured (a) $<1$ year, (b) 1-2 years, or (c) $>2$ years after treatment in annual cropping systems as a function of management techniques. For each management technique, the number next to the confidence interval represents the number of data points that was used to calculate the mean. 


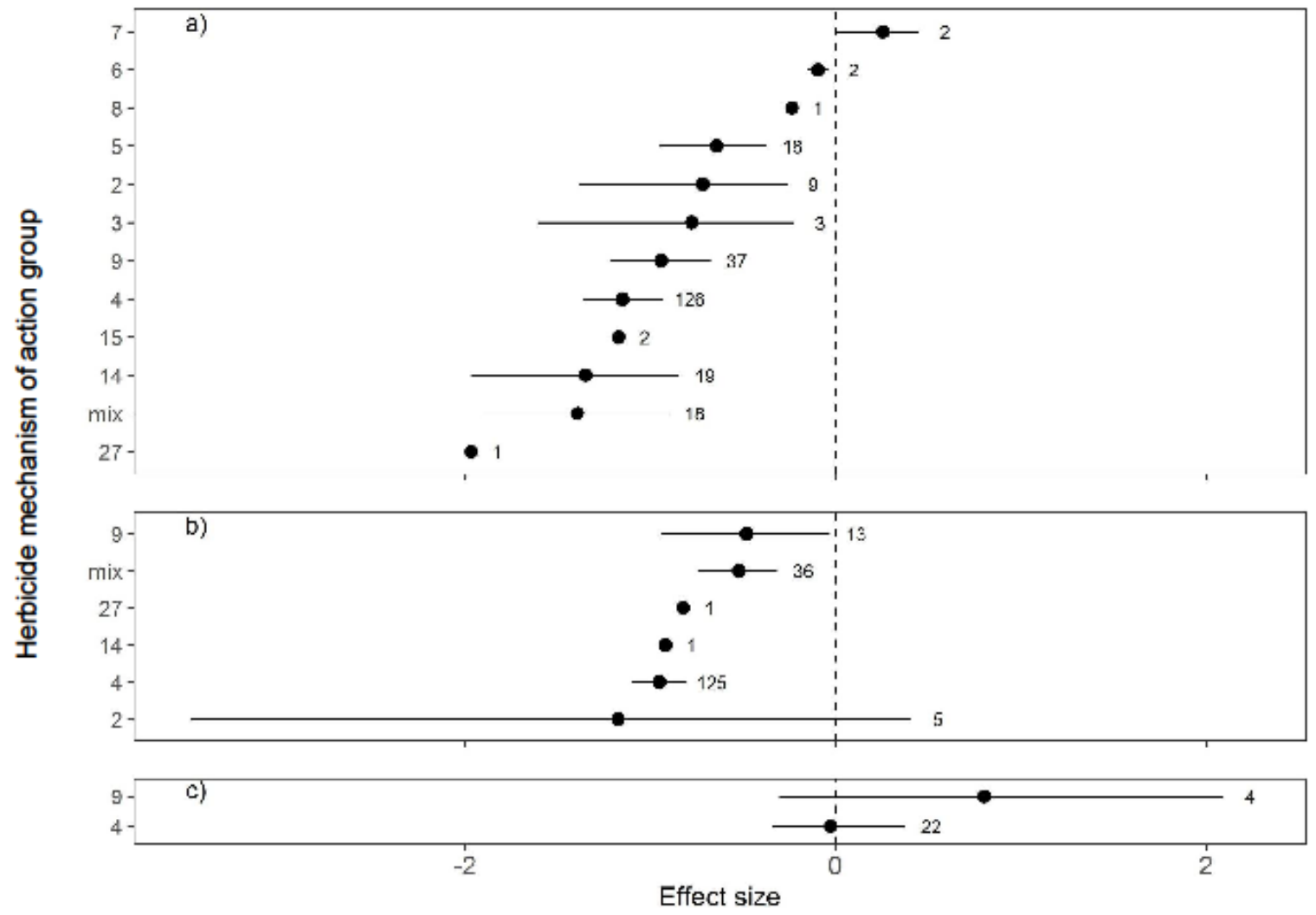

Figure 3. Mean effect size ( $\operatorname{lnR}$ ) and 95\% confidence intervals for field bindweed Convolvulus arvensis abundance measured (a) $<1$ year, (b) 1-2 years, or (c) $>2$ years after treatment in annual cropping systems as a function of herbicide mechanism of action groups. For each group, the number next to the confidence interval represents the number of data points that was used to calculate the mean. Groups are as follows: $2=$ ALS or AHAS inhibitors; $3=$ inhibitors of microtubule assembly; $4=$ synthetic auxins; $5=$ inhibitors of photosynthesis at photosystem II site A; 6= inhibitors of photosynthesis at photosystem II site B; 7= inhibitors of photosynthesis at photosystem II site A (different binding behavior from group 5); 8= inhibitors of lipid synthesis (not ACCase inhibition); 9= inhibitor of EPSPS; 14= inhibitors of protoporphyrinogen oxidase (Protox, PPO); 15= inhibitors of synthesis of very long-chain fatty acids (VLCFA); $27=$ 
inhibitors of 4-hydroxyhenyl-pyruvatedioxygenase (4-HPPD); and mix= includes two or more herbicides from different groups.

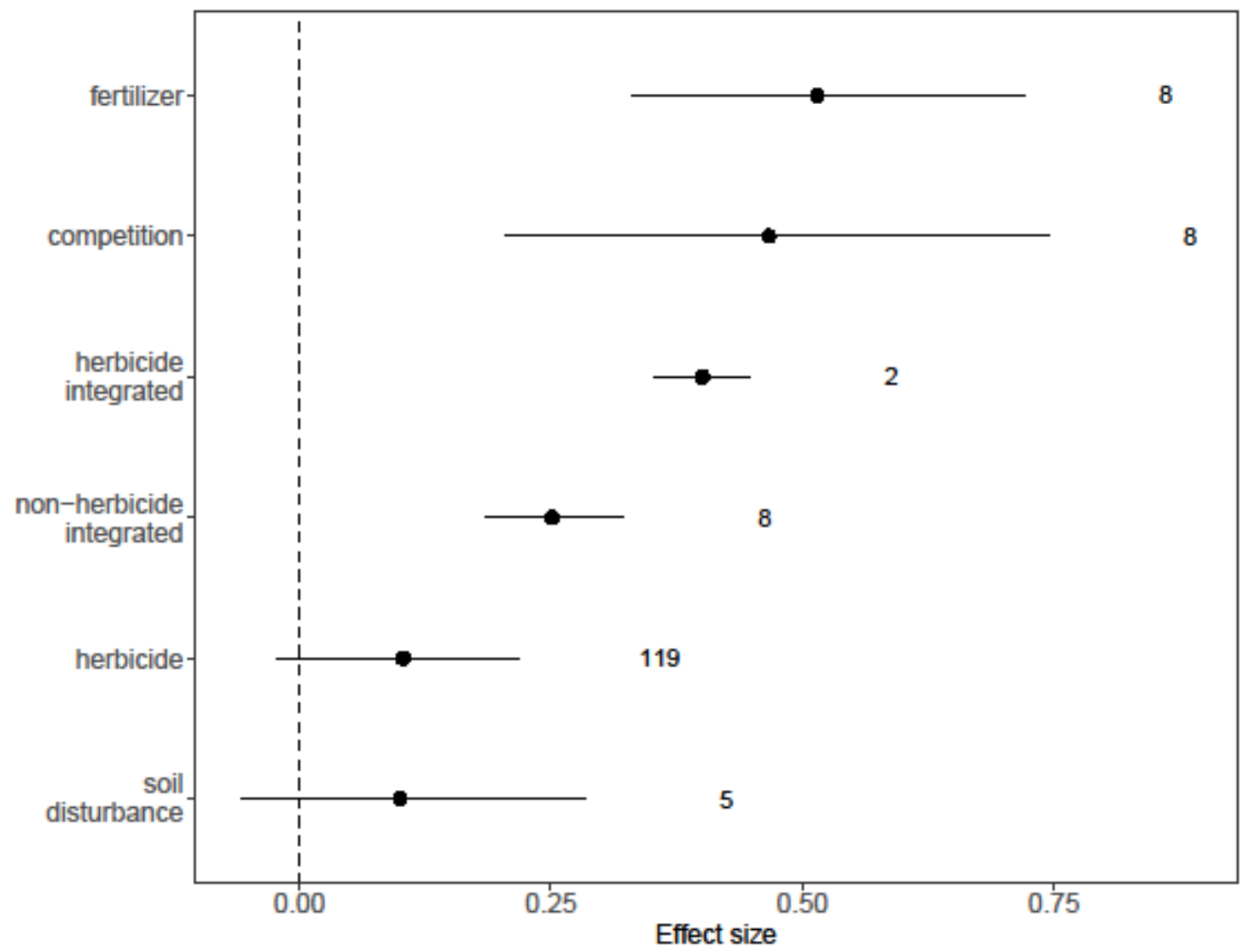

Figure 4. Mean effect size (lnR) and 95\% confidence intervals for crop yield in annual cropping systems as a function of Convolvulus arvensis management techniques. For each management technique, the number next to the confidence interval represents the number of data points that was used to calculate the mean. 


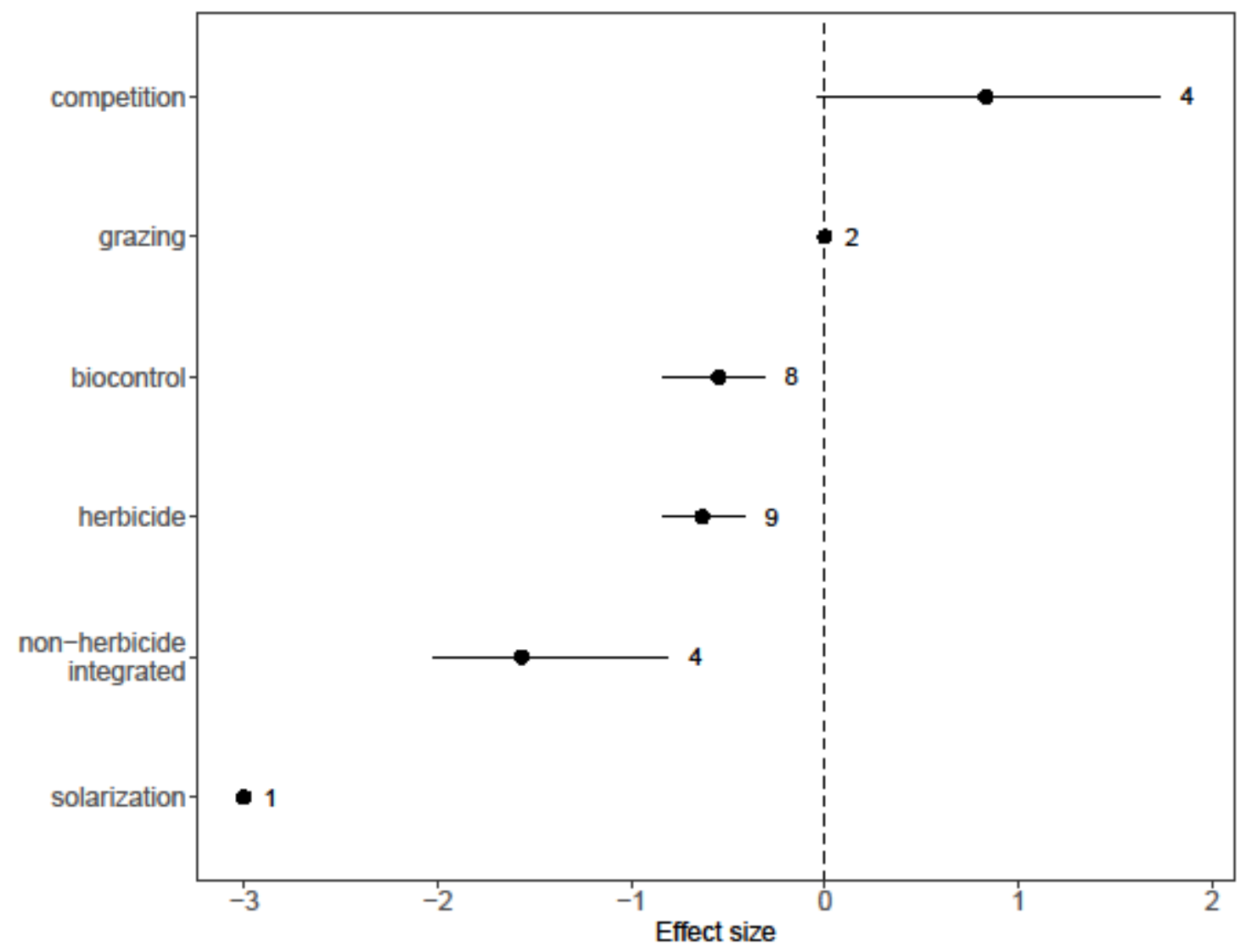

Figure 5. Mean effect size (lnR) and 95\% confidence intervals for Convolvulus arvensis abundance in perennial systems as a function of management techniques. For each management technique, the number next to the confidence interval represents the number of data points that was used to calculate the mean. 
Appendix S1. References used in meta-analysis of Convolvulus arvensis management in annual cropping systems.

Banks PA, Hill LV, Santelmann PW (1979) Control of field bindweed (Convolvulus arvensis) in winter wheat (Triticum aestivum) with foliar and subsurface layered herbicides. Weed Sci $27: 332-335$

Bijanzadeh E, Ghadiri H (2006) Effect of separate and combined treatments of herbicides on weed control and corn (Zea mays) yield. Weed Technol 20:640-645

Bilalis D, Sidiras N, Economou G, Vakali C (2003) Effect of different levels of wheat straw soil surface coverage on weed flora in Vicia faba crops. J Agron Crop Sci 189:233-241

Chhipa KG, Nepalia V (2015) Effect of weed control and phosphorus sources on productivity of wheat (Triticum aestivum). Indian J Agr Res 49:180-184

Davison JG, Bailey JA (1974) The response of Convolvulus arvensis (bindweed) to 2,4-D, MCPA, MCPB, dichlorprop, mecoprop, 2,4,5-T, dicamba and glyphosate at various doses and application dates. Pages 641-648 in Proceedings of the 12th British Weed Control Conference.

Erman M, Tepe I, Yazlik A, Levent R, Ipek K (2004) Effect of weed control treatments on weeds, seed yield, yield components and nodulation in winter lentil. Weed Res 44:305312

Fathi G (2005) Integrated weed management in corn (Zea mays L.). Crop Res 29:40-46

Fathi G (2006) Integrated weed management in common bean (Phaseolus vulgaris L.). Crop Res $31: 33-36$ 
Fujiyoshi PT, Gliessman SR, Langenheim JH (2007) Factors in the suppression of weeds by squash interplanted in corn. Weed Biol Manag 7:105-114

Garcia-Martin A, Lopez-Bellido R, Coleto J (2007) Fertilisation and weed control effects on yield and weeds in durum wheat grown under rain-fed conditions in a Mediterranean climate. Weed Res 47:140-148

Gigax DR, Messersmith CG (1978) Field bindweed control with fall-applied glyphosate and 2,4D. Pages 153-158 in Proceedings of the North Central Weed Control Conference.

Heering DC, Peeper TF (1991) Field bindweed (Convolvulus arvensis) control in winter wheat (Triticum aestivum) with herbicides. Weed Technol 5:411-415

Heisey RM, Heisey TK (2003) Herbicidal effects under field conditions of Ailanthus altissima bark extract, which contains ailanthone. Plant Soil 256:85-99

Jones IB, Evans JO (1973) Control of Russian knapweed and field bindweed with dicamba, 2, 4D and their combinations, with and without DMSO. Pages 39-43 in Proceedings of the Meeting of Western Society of Weed Science.

Karimmojeni H, Pirbaloti AG, Kudsk P, Kanani V, Ghafori A (2013) Influence of postemergence herbicides on weed management in spring-sown linseed. Agron J $105: 821-826$

Kewat M, Pandey J (2001) Effect of pre-emergence herbicides on weed control in soybean (Glycine max). Indian J Agron 46:327-331

Khalil SK, Mehmood T, Rehman A, Wahab S, Khan AZ, Zubair M, Mohammad F (2010) Utilization of allelopathy and planting geometry for weed management and dry matter production of maize. Pak J Bot 42:791-803 
Kleifeld Y (1972) Control of annual weeds and Convolvulus arvensis L. in tomatoes by trifluralin. Weed Res 12:384-388

Knezevic SZ, Datta A, Scott J, Charvat LD (2009) Adjuvants influenced saflufenacil efficacy on fall-emerging weeds. Weed Technol 23:340-345

Knezevic SZ, Datta A, Scott J, Charvat LD (2010) Application timing and adjuvant type affected saflufenacil efficacy on selected broadleaf weeds. Crop Prot 29:94-99

Lehoczky É, Kismányoky A, Németh T (2013) Effects of nutrient supply and soil tillage on the weeds in maize. Commun Soil Sci Plan 44:546-550

Lym RG, Humburg NE (1987) Control of growth-regulator preconditioned field bindweed (Convolvulus arvensis) with herbicides. Weed Technol 1:46-51

MacDonald RT, Hall JC, O'Toole JJ, Swanton CJ (1993) Field bindweed (Convolvulus arvensis) control with fluroxypyr. Weed Technol 7:966-971

Marsalis MA, Renz MJ, Jones SH, Lauriault LM (2008) Managing field bindweed in sorghumwheat-fallow rotations. Crop Manag 7:10.1094/CM2008-0818-01-RS

Mashhadi HR, Evans JO (1987) Field Bindweed Control with Metsulfuron and Other Herbicides. Western Society of Weed Science. p 348-350

Matic R, Black ID (1994) Short- and long-term chemical control of field bindweed (Convolvulus arvensis L.) sprayed during summer and resultant crop yields. Plant Prot Quart 9:111-113

Miller SD (1987) Evaluation of Post Harvest Herbicide Treatments for Field Bindweed Control in Fallow. Western Society of Weed Science. p 347

Miller SD, Neider T (1992a) Field Bindweed Control in Fallow with Fall Herbicide Treatments. Western Society of Weed Science. p 183 
Miller SD, Neider T (1992b) Field Bindweed Control in Fallow and Winter Wheat with Early Summer Treatments. Western Society of Weed Science. p 161-162

Mishra JS, Kurchania SP (2001) Weed dynamics, nutrient uptake, and yield in Indian mustard (Brassica juncea)- weed ecosystem as influenced by nitrogen levels, planting geometry and herbicides. Indian Journal of Agronomy 46:296-303

Mishra JS, Singh VP (2009) Weed dynamics and productivity of soybean (Glycine max)- based cropping systems as influenced by tillage and weed management. Indian J Agron 54:2935

Rao AN (1983) Composition of associated weeds and grain yield of maize as affected by herbicide treatments. Indian J Bot 6:74-78

Schweizer EE, Swink JF (1971) Field bindweed control with dicamba and 2,4-D, and crop response to chemical residues. Weed Sci 19:717-721

Schweizer EE, Swink JF, Heikes PE (1978) Field bindweed (Convolvulus arvensis) control in corn (Zea mays) and sorghum (Sorghum bicolor) with dicamba and 2,4-D. Weed Sci 26:665-668

Singh I, Agarwal SK (2004) Impact of nutrient and weed management on weed dynamics in mustard (Brassica juncea L. Czern and Coss) under dryland conditions. Indian J Agr Res 38:87-93

Stahler LM, Carlson AE (1947) Controlling field bindweed by grazing with sheep. J Am Soc Agron 39:56-64

Stone AE, Peeper TF, Kelley JP (2005) Efficacy and acceptance of herbicides applied for field bindweed (Convulvulus arvensis) control. Weed Technol 19:148-153 
Tolimir M, Veskovic M, Komljenovic I, Djalovic I, Stipesevic B (2006) Influences of soil tillage and fertilization on maize yield and weed infestation. Cereal Res Commun 34:323-326

Vasilakoglou I, Dhima K, Paschalidis K, Gatsis T, Zacharis K, Galanis M (2013) Field bindweed (Convolvulus arvensis L.) and redroot pigweed (Amaranthus retroflexus L.) control in potato by pre- or post-emergence applied flumioxazin and sulfosulfuron. Chil J Agr Res $73: 24-30$

Westra P, Chapman P, Stahlman PW, Miller SD, Fay PK (1992) Field bindweed (Convolvulus arvensis) control with various herbicide combinations. Weed Technol 6:949-955

Westra P, D'Amato T (1988) Fallow Bindweed Control with Picloram Combinations. Western Society of Weed Science. p 2-3

Whitesides RE (1978) Field Bindweed: A Growth Stage Indexing System and Its Relation to Control with Glyphosate. Ph.D. dissertation. Corvallis, OR: Oregon State University. 89 $\mathrm{p}$

Whitson TD, Tuck B (1986) Evaluation of Herbicides for Field Bindweed (Convolvulus arvensis L.) Control and Crop Tolerance. Western Society of Weed Science. p 190

Wiese AF, Gibson J, Lavake D (1967) Controlling large field bindweed infestations with repeated applications of Tordon. Down to Earth 23:37-39

Wiese AF, Lavake DE (1986) Control of field bindweed (Convolvulus arvensis) with postemergence herbicides. Weed Sci 34:77-80

Wiese AF, Lavake DE, Chenault EW (1981) Controlling perennial weeds with picloram. Down to Earth $37: 20-23$

Wiese AF, Schoenhals MG, Bean BW, Salisbury CD (1997) Effect of tillage timing on herbicide toxicity to field bindweed. J Prod Agric 10:459-461 
Wilson RG (1978) Field bindweed control in western Nebraska. Pages 142-144 in Proceedings of the North Central Weed Control Conference. 
1 Appendix S2. References used in meta-analysis of Convolvulus arvensis management in

2 perennial systems.

4 Abu-Dieyeh MH, Watson AK (2007) Grass overseeding and a fungus combine to control Taraxacum officinale. J Appl Ecol 44:115-124

6 Boss D, Schlapfer E, Fuchs J, Defago G, Maurhofer M (2007) Improvement and application of 7 the biocontrol fungus Stagonospora convolvuli LA39 formulation for efficient control of Calystegia sepium and Convolvulus arvensis. J Plant Dis Protect 114:232-238

9 Celebi SZ, Kaya I, Korhan Sahar A, Yergin R (2010) Effects of the weed density on grass yield of alfalfa (Medicago sativa L.) in different row spacing applications. Afr J Biotechnol

12 Elmore CL, Roncoroni JA, Giraud DD (1993) Perennial weeds respond to control by soil solarization. Calif Agr 47:19-22

14 Guntli D, Pfirter HA, Moenne-Loccoz Y, Defago G (1998) Stagonospora convolvuli LA39 for biocontrol of field bindweed infesting cotoneaster in a cemetery. Hortic Sci 33:860-861

16 Heiny DK (1994) Field survival of Phoma proboscis and synergism with herbicides for control of field bindweed. Plant Dis 78:1156-1164

18 Stahler LM, Carlson AE (1947) Controlling field bindweed by grazing with sheep. J Am Soc Agron 39:56-64

20 Timmons FL (1950) Competitive relationships of four different lawn grasses with field bindweed and dandelion under frequent close clipping. Ecology 31:1-5

22 Vore RE (1987) Top Growth Control of Field Bindweed Resulting From Reduced Rate Herbicide Applications. Western Society of Weed Science. p 2 
Table S1. Article information used in meta-analyses of Convolvulus arvensis management in annual cropping systems. Articles that had information on crop yield are indicated by an * next to the citation.

\begin{tabular}{|c|c|c|c|c|c|c|c|}
\hline \multirow[t]{2}{*}{ Citation } & \multirow[t]{2}{*}{ Study location } & \multirow{2}{*}{$\begin{array}{l}\text { Cropping } \\
\text { system }\end{array}$} & \multirow{2}{*}{$\begin{array}{l}\text { Management } \\
\text { technique(s) }\end{array}$} & \multirow{2}{*}{$\begin{array}{l}\text { Herbicide } \\
\text { group }(\mathbf{s})\end{array}$} & \multicolumn{3}{|c|}{ Study duration } \\
\hline & & & & & $\begin{array}{c}<1 \\
\text { year }\end{array}$ & $\begin{array}{c}1-2 \\
\text { years }\end{array}$ & $\begin{array}{c}>2 \\
\text { years }\end{array}$ \\
\hline $\begin{array}{l}\text { Banks et al. } \\
1979^{*}\end{array}$ & Oklahoma, United States & winter wheat & herbicide & $3,4,9,14$ & $\mathrm{X}$ & $\mathrm{X}$ & \\
\hline $\begin{array}{l}\text { Bijanzadeh and } \\
\text { Ghadiri } 2006^{*}\end{array}$ & Shiraz, Iran & corn & herbicide & $2,4,5,15$, mix & $\mathrm{X}$ & & \\
\hline \multirow[t]{3}{*}{ Bilalis et al. 2003} & Athens, Greece & faba bean & mulch & na & $\mathrm{X}$ & & \\
\hline & & & non-herbicide integrated & na & $X$ & & \\
\hline & & & soil disturbance & na & $X$ & & \\
\hline $\begin{array}{l}\text { Chhipa and } \\
\text { Nepalia 2015* }\end{array}$ & Udaipur, India & wheat & herbicide & $2,4,14$ & $\mathrm{X}$ & & \\
\hline $\begin{array}{l}\text { Davison and } \\
\text { Bailey } 1974\end{array}$ & $\begin{array}{l}\text { Oxfordshire, United } \\
\text { Kingdom }\end{array}$ & fallow & herbicide & 4,9 & $\mathrm{X}$ & $\mathrm{X}$ & \\
\hline \multirow{3}{*}{$\begin{array}{l}\text { Erman et al. } \\
2004 *\end{array}$} & Van, Turkey & lentil & herbicide & $5,7,14$ & $\mathrm{X}$ & & \\
\hline & & & herbicide integrated & na & $X$ & & \\
\hline & & & soil disturbance & na & $X$ & & \\
\hline \multirow[t]{2}{*}{ Fathi 2005} & Khoozestan, Iran & corn & herbicide integrated & na & $\mathrm{X}$ & & \\
\hline & & & herbicide & 8 & $\mathrm{X}$ & & \\
\hline Fathi 2006 & Khoozestan, Iran & common bean & soil disturbance & na & $\mathrm{X}$ & & \\
\hline $\begin{array}{l}\text { Fujiyoshi et al. } \\
2007 *\end{array}$ & California, United States & corn & competition & na & $\mathrm{X}$ & & \\
\hline $\begin{array}{l}\text { Garcia-Martin et } \\
\text { al. } 2007 *\end{array}$ & Badajoz, Spain & $\begin{array}{l}\text { diversified } \\
\text { (fallow, } \\
\text { barley, vetch, } \\
\text { durum wheat) }\end{array}$ & soil disturbance & na & $\mathrm{X}$ & & \\
\hline
\end{tabular}


Table S1. Article information used in meta-analyses of Convolvulus arvensis management in annual cropping systems. Articles that had information on crop yield are indicated by an * next to the citation.

\begin{tabular}{|c|c|c|c|c|c|c|c|}
\hline \multirow[t]{2}{*}{ Citation } & \multirow[t]{2}{*}{ Study location } & \multirow{2}{*}{$\begin{array}{l}\text { Cropping } \\
\text { system }\end{array}$} & \multirow{2}{*}{$\begin{array}{l}\text { Management } \\
\text { technique(s) }\end{array}$} & \multirow{2}{*}{$\begin{array}{l}\text { Herbicide } \\
\text { group(s) }\end{array}$} & \multicolumn{3}{|c|}{ Study duration } \\
\hline & & & & & $\begin{array}{l}<1 \\
\text { year }\end{array}$ & $\begin{array}{c}1-2 \\
\text { years }\end{array}$ & $\begin{array}{c}>2 \\
\text { years }\end{array}$ \\
\hline $\begin{array}{l}\text { Gigax and } \\
\text { Messersmith } \\
1978^{*}\end{array}$ & $\begin{array}{l}\text { North Dakota, United } \\
\text { States }\end{array}$ & spring wheat & herbicide & 4,9 & $\mathrm{X}$ & & \\
\hline $\begin{array}{l}\text { Heering and } \\
\text { Peeper 1991* }\end{array}$ & Oklahoma, United States & winter wheat & herbicide & 2 & & $\mathrm{X}$ & \\
\hline $\begin{array}{l}\text { Heisey and } \\
\text { Heisey } 2003\end{array}$ & $\begin{array}{l}\text { Pennsylvania, United } \\
\text { States }\end{array}$ & $\begin{array}{l}\text { cauliflower, } \\
\text { tomatoes, } \\
\text { corn, and } \\
\text { beans }\end{array}$ & bioherbicide & na & $\mathrm{X}$ & & \\
\hline $\begin{array}{l}\text { Jones and Evans } \\
1973\end{array}$ & Utah, United States & fallow & herbicide & 4 & $\mathrm{X}$ & $\mathrm{X}$ & \\
\hline $\begin{array}{l}\text { Karimmojeni et } \\
\text { al. } 2013^{*}\end{array}$ & Najaf Abad County, Iran & flax & herbicide & $4,5,6, \operatorname{mix}$ & $\mathrm{X}$ & & \\
\hline $\begin{array}{l}\text { Kewat and } \\
\text { Pandey } 2001\end{array}$ & New Delhi, India & soybean & herbicide & 3,5 & $\mathrm{X}$ & & \\
\hline $\begin{array}{l}\text { Khalil et al. } \\
2010^{*}\end{array}$ & Peshawar, Pakistan & corn & competition & na & $\mathrm{X}$ & & \\
\hline \multirow[t]{2}{*}{ Kleifeld 1972} & Kibbutz Usha, Israel & fallow & herbicide & 14 & $\mathrm{X}$ & & \\
\hline & & & herbicide integrated & na & $X$ & & \\
\hline $\begin{array}{l}\text { Knezevic et al. } \\
2009\end{array}$ & Nebraska, United States & fallow & herbicide & 14 & $\mathrm{X}$ & & \\
\hline $\begin{array}{l}\text { Knezevic et al. } \\
2010\end{array}$ & Nebraska, United States & fallow & herbicide & 14 & $\mathrm{X}$ & & \\
\hline $\begin{array}{l}\text { Lehoczky et al. } \\
2013\end{array}$ & Keszthely, Hungary & $\begin{array}{l}\text { diversified } \\
\text { (winter wheat, } \\
\text { winter wheat, } \\
\text { maize, maize) }\end{array}$ & soil disturbance & na & $\mathrm{X}$ & & \\
\hline
\end{tabular}


Table S1. Article information used in meta-analyses of Convolvulus arvensis management in annual cropping systems. Articles that had information on crop yield are indicated by an * next to the citation.

\begin{tabular}{|c|c|c|c|c|c|c|c|}
\hline \multirow[t]{2}{*}{ Citation } & \multirow[t]{2}{*}{ Study location } & \multirow{2}{*}{$\begin{array}{l}\text { Cropping } \\
\text { system }\end{array}$} & \multirow{2}{*}{$\begin{array}{l}\text { Management } \\
\text { technique(s) }\end{array}$} & \multirow{2}{*}{$\begin{array}{l}\text { Herbicide } \\
\text { group(s) }\end{array}$} & \multicolumn{3}{|c|}{ Study duration } \\
\hline & & & & & $\begin{array}{c}<1 \\
\text { year }\end{array}$ & $\begin{array}{c}1-2 \\
\text { years }\end{array}$ & $\begin{array}{c}>2 \\
\text { years }\end{array}$ \\
\hline $\begin{array}{l}\text { Lym and } \\
\text { Humburg } 1987\end{array}$ & Wyoming, United States & fallow & herbicide & 4 & & $\mathrm{X}$ & $\mathrm{X}$ \\
\hline $\begin{array}{l}\text { MacDonald et al. } \\
1993\end{array}$ & Ontario, Canada & corn & herbicide & 4 & $\mathrm{X}$ & & \\
\hline $\begin{array}{l}\text { Marsalis et al. } \\
2008\end{array}$ & $\begin{array}{l}\text { New Mexico, United } \\
\text { States }\end{array}$ & $\begin{array}{l}\text { diversified } \\
\text { (sorghum, } \\
\text { wheat, fallow) }\end{array}$ & herbicide & 4 & $\mathrm{X}$ & $\mathrm{X}$ & $\mathrm{X}$ \\
\hline $\begin{array}{l}\text { Mashhadi and } \\
\text { Evans } 1987\end{array}$ & Utah, United States & fallow & herbicide & 4,9 & $\mathrm{X}$ & & \\
\hline $\begin{array}{l}\text { Matic and Black } \\
1994\end{array}$ & $\begin{array}{l}\text { South Australia, } \\
\text { Australia }\end{array}$ & $\begin{array}{l}\text { diversified } \\
\text { (wheat, } \\
\text { barley, field } \\
\text { peas) }\end{array}$ & herbicide & $2,4,9$, mix & $\mathrm{X}$ & $\mathrm{X}$ & \\
\hline Miller 1987 & Wyoming, United States & fallow & herbicide & 4, mix & $\mathrm{X}$ & & \\
\hline $\begin{array}{l}\text { Miller and Neider } \\
1992 \text { (a) }\end{array}$ & Wyoming, United States & fallow & herbicide & 4 & & $\mathrm{X}$ & \\
\hline $\begin{array}{l}\text { Miller and Neider } \\
1992(b)^{*}\end{array}$ & Wyoming, United States & winter wheat & herbicide & 4,9 & $\mathrm{X}$ & $\mathrm{X}$ & \\
\hline \multirow{2}{*}{$\begin{array}{l}\text { Mishra and } \\
\text { Kurchania 2001* }\end{array}$} & Jabalpur, India & mustard & fertilizer & na & $X$ & & \\
\hline & & & herbicide & 7 & $X$ & & \\
\hline $\begin{array}{l}\text { Mishra and Singh } \\
2009\end{array}$ & Madhya Pradesh, India & $\begin{array}{l}\text { diversified } \\
\text { (soybean, } \\
\text { wheat or } \\
\text { soybean, } \\
\text { linseed) }\end{array}$ & herbicide & $\operatorname{mix}$ & $\mathrm{X}$ & & \\
\hline Rao $1983^{*}$ & Ujjain, India & corn & herbicide & 4,5 & $\mathrm{X}$ & & \\
\hline
\end{tabular}


Table S1. Article information used in meta-analyses of Convolvulus arvensis management in annual cropping systems. Articles that had information on crop yield are indicated by an * next to the citation.

\begin{tabular}{|c|c|c|c|c|c|c|c|}
\hline \multirow[t]{2}{*}{ Citation } & \multirow[t]{2}{*}{ Study location } & \multirow{2}{*}{$\begin{array}{l}\text { Cropping } \\
\text { system }\end{array}$} & \multirow{2}{*}{$\begin{array}{l}\text { Management } \\
\text { technique(s) }\end{array}$} & \multirow{2}{*}{$\begin{array}{l}\text { Herbicide } \\
\text { group(s) }\end{array}$} & \multicolumn{3}{|c|}{ Study duration } \\
\hline & & & & & $\begin{array}{c}<1 \\
\text { year }\end{array}$ & $\begin{array}{c}1-2 \\
\text { years }\end{array}$ & $\begin{array}{c}>2 \\
\text { years }\end{array}$ \\
\hline $\begin{array}{l}\text { Schweizer and } \\
\text { Swink } 1971^{*}\end{array}$ & Colorado, United States & $\begin{array}{l}\text { diversified } \\
\text { (sorghum, } \\
\text { sugarbeets, } \\
\text { corn) }\end{array}$ & herbicide & 4 & $\mathrm{X}$ & $\mathrm{X}$ & $\mathrm{X}$ \\
\hline $\begin{array}{l}\text { Schweizer et al. } \\
1978 *\end{array}$ & Colorado, United States & $\begin{array}{l}\text { diversified } \\
\text { (corn, } \\
\text { sorghum) }\end{array}$ & herbicide & 4 & $\mathrm{X}$ & $\mathrm{X}$ & $\mathrm{X}$ \\
\hline \multirow{2}{*}{$\begin{array}{l}\text { Singh and } \\
\text { Agarwal 2004* }\end{array}$} & Hisar, India & mustard & herbicide & 14 & $\mathrm{X}$ & & \\
\hline & & & non-herbicide integrated & na & $X$ & & \\
\hline $\begin{array}{l}\text { Stahler and } \\
\text { Carlson } 1947\end{array}$ & $\begin{array}{l}\text { Minnesota, United } \\
\text { States }\end{array}$ & rye & grazing & na & $\mathrm{X}$ & & \\
\hline Stone et al. 2005 & Oklahoma, United States & winter wheat & herbicide & $4,9, \operatorname{mix}$ & $\mathrm{X}$ & & $\mathrm{X}$ \\
\hline $\begin{array}{l}\text { Tolimir et al. } \\
2006^{*}\end{array}$ & Belgrade, Serbia & corn & soil disturbance & na & $\mathrm{X}$ & & \\
\hline $\begin{array}{l}\text { Vasilakoglou et } \\
\text { al. } 2013^{*}\end{array}$ & $\begin{array}{l}\text { Central and northern } \\
\text { Greece }\end{array}$ & potato & herbicide & 2,14 & $\mathrm{X}$ & & \\
\hline $\begin{array}{l}\text { Westra and } \\
\text { D'Amato } 1988\end{array}$ & Colorado, United States & wheat fallow & herbicide & $4, \operatorname{mix}$ & $\mathrm{X}$ & $\mathrm{X}$ & \\
\hline Westra et al. 1992 & $\begin{array}{l}\text { Colorado and Wyoming, } \\
\text { United States }\end{array}$ & wheat fallow & herbicide & $4, \operatorname{mix}$ & & $\mathrm{X}$ & \\
\hline \multirow[t]{3}{*}{ Whitesides 1979} & Oregon, United States & wheat & soil disturbance & na & $\mathrm{X}$ & & \\
\hline & & & herbicide integrated & na & $X$ & & \\
\hline & & & herbicide & 9 & $X$ & $X$ & \\
\hline $\begin{array}{l}\text { Whitson and } \\
\text { Tuck } 1986\end{array}$ & Oregon, United States & barley & herbicide & 4 & $\mathrm{X}$ & & \\
\hline
\end{tabular}


Table S1. Article information used in meta-analyses of Convolvulus arvensis management in annual cropping systems. Articles that had information on crop yield are indicated by an * next to the citation.

\begin{tabular}{|c|c|c|c|c|c|c|c|}
\hline \multirow[t]{2}{*}{ Citation } & \multirow[t]{2}{*}{ Study location } & \multirow{2}{*}{$\begin{array}{l}\text { Cropping } \\
\text { system }\end{array}$} & \multirow{2}{*}{$\begin{array}{l}\text { Management } \\
\text { technique(s) }\end{array}$} & \multirow{2}{*}{$\begin{array}{l}\text { Herbicide } \\
\text { group }(s)\end{array}$} & \multicolumn{3}{|c|}{ Study duration } \\
\hline & & & & & $\begin{array}{c}<1 \\
\text { year }\end{array}$ & $\begin{array}{c}1-2 \\
\text { years }\end{array}$ & $\begin{array}{c}>2 \\
\text { years }\end{array}$ \\
\hline \multirow{2}{*}{$\begin{array}{l}\text { Wiese and } \\
\text { Lavake } 1986\end{array}$} & Texas, United States & fallow & herbicide & $4, \operatorname{mix}$ & & & $\mathrm{X}$ \\
\hline & & & herbicide integrated & na & & $\mathrm{X}$ & \\
\hline \multirow[t]{2}{*}{ Wiese et al. 1967} & Texas, United States & fallow & herbicide & 4 & $X$ & $X$ & \\
\hline & & & soil disturbance & na & $\mathrm{X}$ & & \\
\hline Wiese et al. 1981 & Texas, United States & na & herbicide & 4 & & $\mathrm{X}$ & \\
\hline Wiese et al. 1997 & Texas, United States & fallow & herbicide integrated & na & $\mathrm{X}$ & & \\
\hline \multirow[t]{2}{*}{ Wilson 1978} & Nebraska, United States & winter wheat & herbicide & $4,9,27$ & $\mathrm{X}$ & $\mathrm{X}$ & \\
\hline & & $\begin{array}{l}\text { field beans- } \\
\text { alfalfa }\end{array}$ & herbicide & 4,9 & & $\mathrm{X}$ & $\mathrm{X}$ \\
\hline
\end{tabular}


Table S2. Article information used in meta-analysis of Convolvulus arvensis management in perennial systems.

\begin{tabular}{|c|c|c|c|}
\hline Citation & Study location & Perennial system description & $\begin{array}{l}\text { Management } \\
\text { technique(s) }\end{array}$ \\
\hline Abu-Dieyeh et al. 2007 & Quebec, Canada & lawn & $\begin{array}{l}\text { competition } \\
\text { biocontrol } \\
\text { non-herbicide integrated }\end{array}$ \\
\hline Boss et al. 2007 & Switzerland & meadow & biocontrol \\
\hline Celebi et al. 2010 & Van, Turkey & alfalfa & competition \\
\hline Elmore et al. 1993 & California, United States & turf & $\begin{array}{l}\text { solarization } \\
\text { herbicide }\end{array}$ \\
\hline Guntli et al. 1998 & Zurich, Switzerland & cemetery & biocontrol \\
\hline Heiny 1994 & Colorado, United States & smooth brome field & $\begin{array}{l}\text { biocontrol } \\
\text { herbicide }\end{array}$ \\
\hline $\begin{array}{l}\text { Stahler and Carlson } \\
1947\end{array}$ & Minnesota, United States & $\begin{array}{l}\text { alfalfa-bromegrass or alfalfa-reed } \\
\text { canarygrass }\end{array}$ & grazing \\
\hline Timmons 1950 & Kansas, United States & lawn & $\begin{array}{l}\text { non-herbicide integrated } \\
\text { competition }\end{array}$ \\
\hline Vore 1987 & Wyoming, United States & intermediate wheatgrass & herbicide \\
\hline
\end{tabular}

